\title{
O herói roseano: Augusto Matraga, da violência à santidade
}

Vanessa Riambau*

Resumo: O objetivo deste trabalho é analisar o conto "A hora e a vez de Augusto Matraga", de Guimarães Rosa, observando de que forma acontece a trajetória do herói, bem como sua evolução. Para tanto, atentaremos aos aspectos simbólicos constantes na trama, assim como evidenciaremos a importância da viagem efetuada pelo herói para o seu desfecho.

\begin{abstract}
The aim of this work is to analyse the short story "A hora e a vez de Augusto Matraga", by Guimarães Rosa, observing how the journey of the hero and its evolution appear in the text. In order to do so, we will take into account the symbolic aspects that constantly arise in the plot, as well as highlight the importance of the hero's journey for the conclusion of the story.
\end{abstract}

Keywords: short story; Guimarães Rosa; hero; journey.
Palavras-chave: conto; Guimarães Rosa; herói; trajetória.

É preciso ter cuidado para se falar sobre Guimarães Rosa. Quase tudo já foi dito, e o que ainda não foi está impresso na subjetividade de seus críticos e leitores. Ao falarmos sobre "A hora e a vez de Augusto Matraga", a dificuldade inicial está em definir seu formato. Conto ou novela? Apesar de estar publicado em uma coletânea de $\operatorname{contos}^{1}$, sua estrutura assemelhase à de uma novela. De acordo com o antropólogo Roberto DaMatta ${ }^{2}$, a narrativa é uma novela. Essa terminologia se faz necessária para o referencial teórico que será usado posteriormente.

O protagonista inicial da trama não é Augusto Matraga, e sim Augusto Esteves, ou Nhô Augusto. Augusto Matraga ainda não existe: Augusto Esteves, Nhô Augusto ou Augusto Matraga são faces diferentes de um mesmo personagem. Logo na frase inicial da trama, o narrador nos fornece uma pista essencial ao entendimento da narrativa: "Matraga não é Matraga, não é nada" (ROSA, 1984, p. 341). Cito DaMatta:

A novela começa com Nhô Augusto, que se transforma em Matraga apenas no final, podendose considerar a mensagem narrativa como o estudo desse processo de transformação de um

\footnotetext{
* Vanessa Riambau é aluna na área de Estudos Literários do Programa de Pós-Graduação em Letras da Universidade Federal do Rio Grande do Sul.

${ }^{1}$ ROSA, João Guimarães. Sagarana. Rio de Janeiro: Nova Fronteira, 1984

${ }^{2}$ DAMATTA, Roberto. Carnavais, malandros e heróis. Rio de Janeiro: Rocco, 1981.
} 
nome em outro - de um homem em outro, já que tais designações são índices fortemente marcados de identidades sociais desempenhadas por seu portador (1981, p. 245)

Inicialmente, é apresentado-nos Augusto Esteves, familiarmente conhecido como Nhô Augusto. As poucas cenas que se dão nesse desenrolar inicial servem apenas para denotar o caráter frio e violento do personagem, descrito como um homem "duro, doido e sem detença, como um bicho grande do mato" (ROSA, 1984, p. 346) e indiferente com a mulher e a filha: "Nem com a menina se importava. Dela, Dionóra, gostava, às vezes; da sua boca, das suas carnes. Só" (1984, p. 346). A narrativa inicia com um leilão, em que Nhô Augusto arremata uma prostituta pelo valor de 50 mil réis. Faz isso por vaidade, pois aborrece um capiau que havia se encantado com a moça só para desdenhá-la: "Você tem perna de manuel-fonseca, uma fina e outra seca" (1984, p. 345). O que se percebe é a clara intenção do narrador em delimitar as fases do personagem, apresentado primeiramente como um fazendeiro poderoso, cercado de capangas, prestigiado pelo povo e temido pela mulher e filha.

O que nos é mostrado a seguir é o total declínio desse poderio: abandonado pela mulher, traído por seus capangas que se filiam ao seu inimigo, Major Consilva; marcado como gado e dado como morto, Nhô Augusto tem agora a oportunidade de reavaliar suas atitudes. Quando recebe a visita de um padre, na casa do casal que o cuidou, Nhô Augusto revê a possibilidade de apegar-se a Deus, possibilidade essa perdida ainda na infância quando, ao invés de ceder à avó, que o criou como cristão e o queria padre, preferiu seguir o caminho de seu tio criminoso e a influência de seu pai covarde. A sentença dada pelo padre a Nhô Augusto é a total renúncia:

Você nunca trabalhou, não é? Pois agora, por diante, cada dia de Deus você deve trabalhar por três, e ajudar os outros, sempre que puder. Modere esse seu mau gênio: faça de conta que ele é um poldro bravo, e que você é mais mandante do que ele... Peça a Deus assim, com essa jaculatória: "Jesus manso e humilde de coração, fazei meu coração semelhante ao vosso..." (ROSA, 1984, p. 356).

Ainda mais intensa que a renúncia, é a ascese a que Nhô Augusto voluntariamente se propõe: "nunca mais seria gente [...]. E tomara um tão grande horror às suas maldades e aos seus malfeitos passados, que nem podia se lembrar; e só mesmo rezando" (ROSA, 1984, p. 357). A partir de então, o personagem decide modificar suas atitudes e assegurar sua entrada ao céu: "eu vou prá o céu, e vou mesmo, por bem ou por mal!... E a minha vez há de chegar... Prá o céu eu vou, nem que seja a porrete!" (ROSA, 1984, p. 357).

$\mathrm{O}$ protagonista resolve então ir viver em um sítio que ainda tinha em seu nome, juntamente com o casal que o salvou da morte. Essa viagem torna-se, portanto, o primeiro passo na transformação íntima de Nhô Augusto, que em seu novo lar, o povoado do 
Tombador, comporta-se de maneira totalmente diferente do passado, e é encarado como um homem "meio doido e meio santo". (ROSA, 1984, p. 358).

Conforme o filósofo Arthur Schopenhauer em sua obra $O$ mundo como vontade $e$ como representação ${ }^{3}$, o homem é um ser em constante insatisfação porque deseja e, ao ter seu desejo realizado, sente-se entediado, até que um novo desejo se concretize. Podemos confirmar tal afirmativa na trajetória do herói: Nhô Augusto, agora se transformando em Augusto Matraga, evita a insatisfação inerente ao homem inibindo a própria tentação ao desejo: "não fumava mais, não bebia, não olhava para o bom-parecer das mulheres, não falava junto em discussão" (ROSA, 1984, p. 359). Renegando vontades próprias do ser humano, o personagem se anula enquanto indivíduo, igualando-se a um reles animal: "ele não tinha tentações, nada desejava, cansava o corpo no pesado e dava rezas para a sua alma, tudo isso sem esforço nenhum, como os cupins que levantavam no pasto murundus vermelhos, ou como tico-ticos, que penam sem cessar" (ROSA, 1984, p. 359).

A ascese aparece, então, como o segundo passo no processo de individuação do protagonista, em conflito com sua própria natureza, renegada mas não perdida. De acordo com DaMatta (1981, p. 252), "no caso dos renunciadores, existe uma progressiva individualização, rompendo-se irremediavelmente os laços que ligam o personagem à sua formação social original".

Outrossim, atentos à evidente simbologia bíblica presente no texto, percebemos a seguir a primeira das três tentações que, como Cristo ao se deparar com Satanás no deserto (Mt 4:1-11), Augusto Matraga, em sua via-crucis, enfrenta. Um conhecido de Augusto Matraga o reconhece e transmite-lhe notícias desagradáveis: sua mulher vive com outro e pensa em se casar, sua filha tornara-se prostituta; e Quim, recadeiro, o único de seus homens que permaneceu fiel, morreu defendendo Matraga. Augusto Matraga quis desistir de sua vida de privações e ir à desforra: mas conteve-se. E é nessa contrição que se rompe - um dos mais importantes elos de Matraga com seu passado. Conforme DaMatta:

\begin{abstract}
Inibindo sua vingança, Matraga rompe com os elos de reciprocidade e desfaz definitivamente o mecanismo que o prendia à sociedade. Ele se torna um indivíduo, precisamente porque deixa de retornar, assumindo pela vingança sua posição complementar numa hierarquia. Matraga, então, rompe com sua sociedade e com a hierarquia nela vigente, criando um espaço especial para sua existência. E assim que deixa de ser um vingador, abandona o sistema hierárquico onde ocupava uma alta posição e abre um caminho para seu destino e o quanto afinal decidem do mesmo modo reagir contra o mundo social estabelecido (1981, p.252-253)
\end{abstract}

Passam-se sete anos desde a morte de Augusto Matraga como Nhô Esteves "não tem mais nenhum Nhô Augusto Esteves, das Pindaíbas, minha gente?!... E os cacundeiros, em

\footnotetext{
${ }^{3}$ SCHOPENHAUER, Arthur. O mundo como vontade e como representação. RJ: Contraponto, 2001.
} 
coro: - não tem não! Tem mais não!..." (ROSA, 1984, p.352), e o número indica o fechamento de um ciclo: "e havendo Deus acabado no dia sétimo a sua obra que tinha feito, descansou no sétimo dia de toda sua obra que tinha feito. E abençoou Deus o dia sétimo, e o santificou; porque nele descansou de toda a sua obra" (Gn 2:2,3). A partir de então, ocorre o início da reconciliação do herói com sua própria natureza e com o mundo em que vive.

Segundo Georg Lukács $(2000)^{4}$, existe uma espécie de narrativa específica, considerada de formação, em que é mostrada a trajetória de um herói em conflito para se reconciliar interna e externamente. Em geral, somente após alguns anos de distanciamento temporal e de aprendizado o personagem consegue alcançar esse equilíbrio. Consideramos Augusto Matraga um desses personagens em busca de um aprimoramento e de uma forma de se conciliar consigo e com o restante do mundo. Fundamentamos essa afirmação na própria trajetória do herói que, após ser expulso da sociedade em que vivia e dado como morto, reinicia sua vida, expiando seus crimes e portando-se como um santo. É o supremo rompimento, por parte do personagem, com a sua natureza violenta e passional. Após sete anos de privação, gradualmente Nhô Augusto começa a reencontrar-se e caminhar rumo ao equilíbrio alma/mundo exterior. Cito Lukács:

Seu tema é a reconciliação do indivíduo problemático, guiado pelo ideal vivenciado, com a realidade social concreta. Essa reconciliação não pode nem deve ser uma acomodação ou uma harmonia existente desde o início [...]. Tipo humano e estrutura da ação, portanto, são condicionados aqui pela necessidade formal de que a reconciliação entre interioridade e mundo seja problemática mas possível (2000, p. 138).

Esse retorno a si é marcado por uma simbiose do personagem com os animais e com a própria natureza; vimos que, anteriormente, Matraga se equiparava aos animais como cupins e tico-ticos. E é essa mesma natureza, dos animais pequenos, da vegetação rasteira, que dá indícios do processo de individuação do herói, sua redescoberta enquanto pessoa.

Até que pouco a pouco, devagarinho, imperceptível, alguma cousa pegou a querer voltar para
ele, e crescer-lhe do fundo para fora, sorrateira como a chegada do tempo das águas, que vinha
vindo paralela: com o calor dos dias aumentando, e os dias cada vez maiores, e o joão-de-barro
construindo casa nova, e as sementinhas, que hibernavam na poeira, esperando na poeira, em
misteriosas incubações. Nhô Augusto tinha agora muita fome e muito sono [...]. Nhô Augusto
sentia agora saudades de mulheres. E a força da vida nele latejava, em ondas largas, numa
tensão confortante, que era um regresso e um ressurgimento (ROSA,1984, p.363-373).

Nesse momento de aparente harmonia, o personagem sofre, então, sua segunda tentação. Com a chegada do bando de Joãozinho Bem-Bem, Matraga sente-se tentado a seguir viagem junto com o bando e a retornar a sua violência original. Porém, mais uma vez, resiste.

\footnotetext{
${ }^{4}$ LUKÁCS, Georg. A teoria do romance. São Paulo: Editora 34, 2000.
} 
"Não me tenta, que eu não posso, seu Joãozinho Bem-Bem [...]. Mas, qual, aí era que se perdia, mesmo, que Deus o castigava com a mão mais dura..." (ROSA, 1984, p. 371-372).

Com a partida do bando, Matraga decide partir também sem rumo conhecido. É essa então sua derradeira viagem e ela possui um fundamental papel em seu processo transformador. Talvez de forma inconsciente, o herói acaba fazendo o caminho de volta ao arraial do Murici onde morava quando ainda era Nhô Esteves. Mas não chegou até esse destino. Ficou em um local próximo, o arraial do Rala-Coco, e tal atitude demonstra que a trajetória do personagem não era de desforra ou de retomada de sua vida, e sim de redescobrimento e conscientização. Augusto Matraga não poderia voltar para o mesmo lugar se, há muito, já não era mais o mesmo. O retorno ocorre, mas Matraga não termina seu caminho no local onde vivia antes da transformação, o que denota sua transformação pessoal.

Essa viagem assinala um equilibrar dos mundos interno e externo do personagem e acaba respondendo a dúvida final do herói: como ir para o céu, ser bom homem, sem para isso precisar se despojar de sua verdadeira identidade?

Ao reencontrar o bando de Joãozinho Bem-Bem, o herói sofre sua terceira e última tentação: descobre que um dos rapazes do bando havia sido morto, é-lhe oferecida a oportunidade de ficar com as armas do falecido e de seguir viagem junto ao bando, substituindo o que se fora. "Nhô Augusto bateu a mão na winchester, do jeito com que um gato poria a pata num passarinho. Alisou coronha e cano. E seus dedos tremiam, porque essa estava sendo a maior de suas tentações" (ROSA, 1984, p. 380).

Desde o primeiro encontro de Augusto Matraga e Joãozinho Bem-Bem, houve uma espécie de empatia intensa entre os dois. "Eu gostei da sua pessoa, em-desde a primeira hora, quando o senhor caminhou para mim, na rua daquele lugarejo..." (ROSA, 1984, p.380). Percebemos que, apesar do temperamento atualmente pacífico de Augusto, algum traço original de si se punha latente, e aflorava aos olhos do chefe do bando, como ele mesmo confessou:

O senhor não me contou coisa nenhuma de sua vida, mas eu sei que já deve ter sido brigador de ofício. Olha: eu, até de longe, com os olhos fechados, o senhor não me engana: juro como não há outro homem p'ra ser mais sem medo e disposto para tudo. É só o senhor mesmo querer...(ROSA, 1984, p.380).

Resistindo afinal a sua última tentação, "não posso, meu amigo seu Joãozinho BemBem!... Depois de tantos anos...'(ROSA, 1984, p.381), Augusto Matraga tem, afinal, a oportunidade de fazer um bem que afinal o redimisse de seus erros, alcançando assim, "sua hora e sua vez" (ROSA, 1984, p.273). Sabendo da natural violência do herói, aparece a única 
possibilidade de ele alcançar o esperado equilíbrio entre a renúncia ao mundo a que se propôs e a latente vontade de agir de acordo com sua costumeira agressividade. Conforme Lukács:

\begin{abstract}
A humanidade, como escopo fundamental desse tipo de configuração, requer um equilíbrio entre atividade e contemplação, entre vontade de intervir no mundo e capacidade receptiva em relação a ele [...]. Há que se ver sucumbir fileiras inteiras de homens graças à sua incapacidade de adaptação, e outros ressequir e murchar em virtude de sua capitulação precipitada e incondicional perante toda a realidade, a fim de avaliar o perigo a que todos se expõem e contra o qual existe, certamente, um caminho de salvação individual (2000, p. 141-142).
\end{abstract}

Afinal, a esperada hora surge quando Augusto Matraga depara-se com um velho a quem o bando de Joãozinho Bem-Bem estava disposto a matar a família em vingança pelo comparsa do bando que havia sido assassinado. Inicialmente, o herói compactua com a intenção do amigo, resguardando-se de emitir opiniões. Porém, o velho, ameaçado, implora pela "Virgem Santíssima" (ROSA,1984, p.381), "pelo sangue de Jesus Cristo e pelas lágrimas de Virgem Maria" (1984, p.382), "pelo corpo de Cristo na Sexta-Feira da Paixão" (ROSA, 1984, p.382) e, finalmente, pela "força de Deus" (ROSA, 1984, p. 382). Matraga, que se supunha um discípulo desse mesmo Deus a quem o velho suplicava ajuda, sentiu-se, então, impelido a intervir. "Não faz isso, meu amigo seu Joãozinho Bem-Bem, que o desgraçado do velho está pedindo em nome do Nosso Senhor e da Virgem Maria!" (ROSA, 1984, p. 382). Cito DaMatta:

A intervenção de Matraga transforma-o em representante do Bem, em oposição ao representante do Mal. E tem, ainda, a força de um exorcismo, separando definitivamente seu lado vingativo do seu lado renunciador [...]. O fechamento do ciclo de Matraga, portanto, e realizado no momento em que ele impede um vingador profissional (um bandido social) de exercer sua vingança (1981, p. 255).

Dessa forma, percebemos que acontece um retorno à real essência do herói, de natureza violenta, que agora é utilizada em prol de alguém que pede em nome de Deus. Para defender o homem, o protagonista dispõe-se a lutar com seu amigo Joãozinho Bem-Bem: "Se entregue, mano velho, que eu não quero lhe matar" (ROSA, 1984, p.410), pedindo sempre o auxílio de Deus, "nomopadrofilhospritossantamêin" (ROSA, 1984, p. 410). Nesse instante, ocorre em Nhô Augusto o último movimento de seu processo evolutivo: ele torna-se, afinal, completamente Matraga: "E a casa matraqueou que nem panela de assar pipocas, escurecido à fumaça dos tiros" (ROSA, 1984, p. 410). Convertido em Matraga, Augusto Esteves pôde, afinal, reassumir sua violência íntima e sua alegria de viver: "Ô gostosura de fim-de-mundo!" (ROSA, 1984, p. 410). A força e a violência, causas de sua desgraça anterior, agora ratificam sua salvação.

Ao morrer, Augusto Matraga reconcilia-se com a família, pois descobre um primo no velho que morreu para proteger e abençoa a filha e a ex-esposa. Não obstante, reconcilia-se 
com sua essência agressiva, usada para o bem, e transforma-se, de vilão em santo, de maldito em abençoado: "não deixem este santo morrer assim" (ROSA, 1984, p. 413). Comparado a Jesus Cristo "foi Deus quem mandou esse homem no jumento, por mor de salvar as famílias da gente" (ROSA, 1984, p.413), Matraga morre num "sério contentamento" (ROSA, 1984, p.414), cumprindo sua função de mártir e de santo. Porém, como não poderia deixar de ser, Matraga foi um santo guerreiro e cumpriu sua palavra, pois, como ele mesmo já havia sentenciado, "prá o céu eu vou, nem que seja a porrete!" (ROSA, 1984, p.357). Matraga foi.

\section{Referências}

BÍBLIA SAGRADA. São Paulo: Paulus, 1990.

DAMATTA, Roberto. Carnavais, malandros e heróis. Rio de Janeiro: Rocco, 1981.

LUKÁCS, Georg. A teoria do romance. São Paulo: Editora 34, 2000.

ROSA, João Guimarães. Sagarana. Rio de Janeiro: Nova Fronteira, 1984.

SCHOPENHAUER, Arthur. O mundo como vontade e como representação. Rio de Janeiro: Contraponto, 2001. 